\title{
Permaculture, Education and Enterprise for the Sustainable Development Goals in Lesotho
}

\author{
Ivan Yaholnitsky \\ Bethel Business and Community Development Centre, Lesotho.
}

How to cite this paper: Ivan Yaholnitsky. (2020) Permaculture, Education and Enterprise for the Sustainable Development Goals in Lesotho. Journal of Humanities, Arts and Social Science, 4(2), 165-186. DOI: $10.26855 /$ jhass.2020.07.011

Received: November 6, 2020

Accepted: November 30, 2020

Published: December 18, 2020

${ }^{*}$ Corresponding author: Ivan Yaholnitsky, Bethel Business and Community Development Centre, Lesotho.

Email: ivan.yaholnitsky@gmail.com

\begin{abstract}
This paper is a case study of a technical and commercial school in Lesotho committed to sustainable development. Its name is Bethel Business and Community Development Centre (BBCDC). The research traces the development of BBCDC by examining particular strategies that were implemented, and summarizes the important achievements using the Sustainable Development Goals (SDGs) as a template. Three general themes will be covered: Permaculture, Education and Enterprise with reference to how these knit into the SDGs. It also adds a historical sequence which ties the interdependence and correlation of this triad. The programs and activities reflect movement towards an alternative future guided by the precepts of sustainable development. A broad range of impact assessment metrics will be presented as a basis for validity along with moral and practical justification, natural science and reason.
\end{abstract}

\section{Keywords}

Permaculture, Experiential Education, Enterprise, SDGs, Anti-Fragile, Design

\section{List of Abbreviations.}

$\begin{array}{ll}\text { AC } & \text { Alternating Current } \\ \text { ADB } & \text { African Development Bank } \\ \text { BBCDC } & \text { Bethel Business and Community Development Centre } \\ \text { BRI } & \text { Brace Research Institute - McGill University } \\ \text { COP } & \text { Convention of the Parties (Climate Change) } \\ \text { DC } & \text { Direct Current } \\ \text { FAO } & \text { Food and Agriculture Organization } \\ \text { IRENA } & \text { International Renewable Energy Agency } \\ \text { kW } & \text { Kilowatt } \\ \text { kWh } & \text { Kilowatt hour } \\ \text { LNDC } & \text { Lesotho National Development Corporation } \\ \text { LHDA } & \text { Lesotho Highlands Development Authority } \\ \text { LRA } & \text { Lesotho Revenue Authority } \\ \text { MIT } & \text { Massachusetts Institute of Technology } \\ \text { MJ } & \text { Mega Joule } \\ \text { MOET } & \text { Ministry of Education and Training } \\ \text { MW } & \text { Mega Watt } \\ \text { NUL } & \text { National University of Lesotho }\end{array}$




$\begin{array}{ll}\text { OCF } & \text { Our Common Future } \\ \text { OFID } & \text { OPEC Fund for International Development } \\ \text { OVI } & \text { Objectively Verifiable Indicator } \\ \text { PDC } & \text { Permaculture Design Certificate } \\ \text { SADC } & \text { Southern African Development Community } \\ \text { SDG } & \text { Sustainable Development Goal } \\ \text { SMME } & \text { Small Medium and Micro Enterprises } \\ \text { STEM } & \text { Science Technology Engineering and Mathematics } \\ \text { TVET } & \text { Technical Vocational Education and Training } \\ \text { USD } & \text { United States Dollar } \\ \text { USPC } & \text { United States Peace Corp } \\ \text { WB } & \text { World Bank } \\ \text { WCED } & \text { World Commission on Environment and Development } \\ \text { WUSC } & \text { World University Services of Canada }\end{array}$

\section{Introduction}

The school is located $250 \mathrm{~km}$ south of the capital Maseru as shown in Figure 1. Lesotho is a landlocked country at high altitude in Southern Africa with a population of 2 million and 35,000 square km in area (World Bank, 2020). The country is experiencing the tumult, struggle and exhilaration of emerging as a sovereign country within a condensed time frame, going from a loose assembly of nomadic pastoralists 120 years ago, to independence in 1966 and now in the full throes of modernization and globalization. Contextual information from recent sources indicate the following: Lesotho depends on South Africa for over $90 \%$ of its goods and services; unemployment is estimated at 32.8\% and 43.2\% for youths aged $15-24 ; 80 \%$ of employment is in textiles, apparel, wholesale and retail sectors where wages are minimal (World Bank/UNDP, 2020). Eric Voegelin provides a pithy summary of historical succession experienced by peoples as a fact of life since the beginning of civilization (Voegelin, 1987). BBCDC is an element of this story. Parallel to Voegelin's sober assessment of the human condition, in 1987 the World Commission on Environment and Development (WCED) published Our Common Future (OCF), a comprehensive analysis of global stress, risk and options (WCED, 1987). BBCDC embraces the reasons, impulse and alternatives described by the WCED in OCF, and will be of interest to students of governance, education, institutions, environmental science and sustainable development.

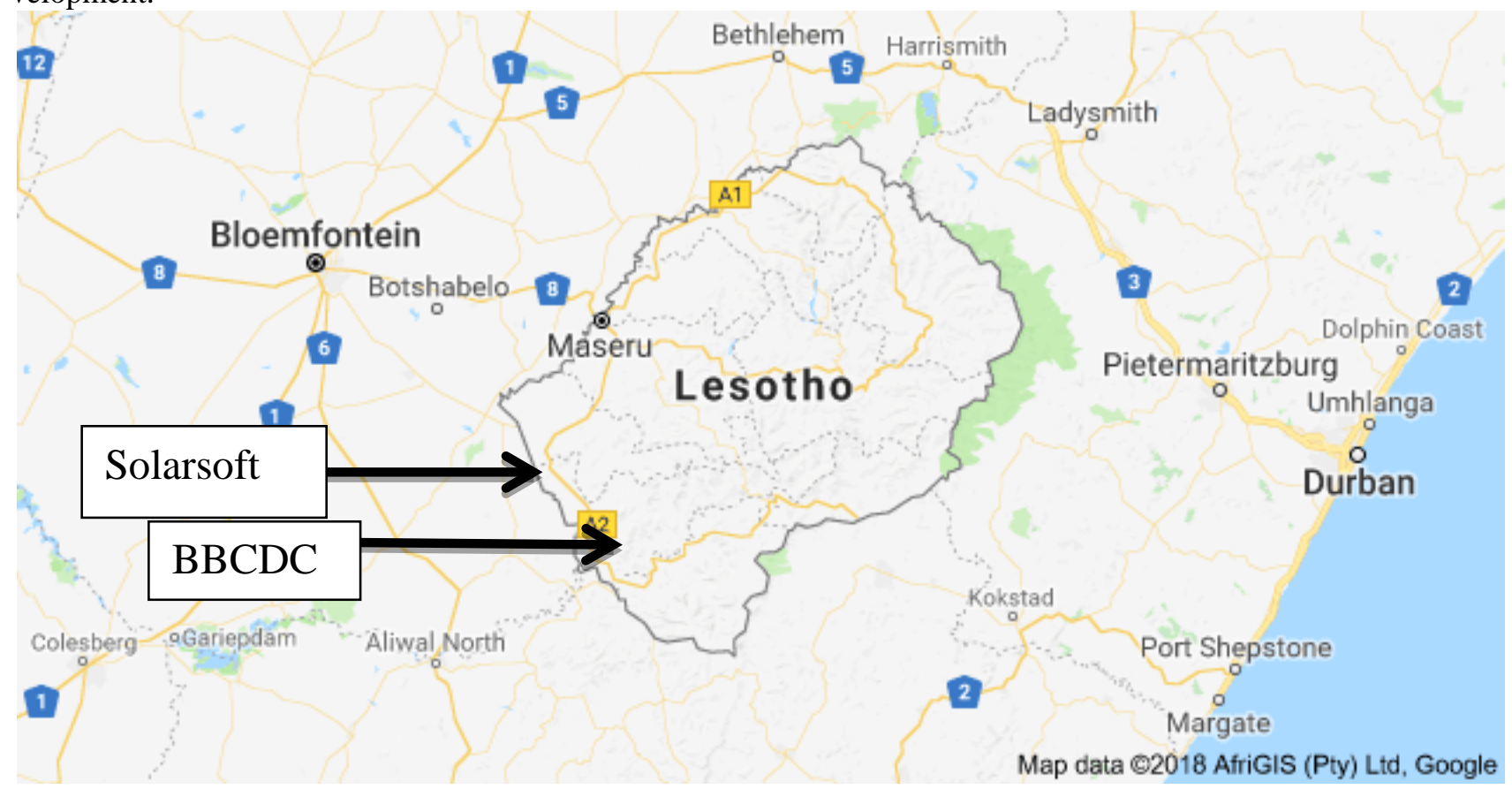

Figure 1. Map of Lesotho and pertinent locations. 
Operations began in January 1993 on barren land with support from UNICEF and the local Roman Catholic Mission which partitioned 4 ha for the use of the school. The initiative set out to address several thorny and interdependent development problems, including: educational innovation, landscape regeneration, water resources improvement, financial independence, adoption of renewable energy platforms, appropriate technology, and design of the built environment for sustainability. Complex systems are key drivers of wealth, value and order creation (Beinhocher, 2006). Lesotho suffers from moderate to severe land degradation and high levels of youth unemployment and the school promotes a rational and cohesive transition pathway (ADB, 2020). The WCED and Bill Mollison's Permaculture: A Designer's Manual 1988 provide intellectual inspiration (Mollison, 1988). By 1996, the purpose of the organization was formalized to provide stakeholders with precision and legitimacy:

Mission Statement: To design and manage innovative learning environments for young men and women in Lesotho that elicits general engineering skills, business sense, manual capabilities, applied sciences, systems thinking, leadership and management abilities that address the needs of career and business development in Lesotho, and general self-reliance. The school also pursues financial self-sustainability through self-reliance, commercial activity and responsible environmental management.

Strategies: To employ Experiential Learning, Permaculture, Sustainable Development, Earth Systems Science and Renewable Energy to achieve rapid economic growth.

Primary Fields of Operation: Education, Self-reliance, Research and Development, Extension and Business Enterprise.

Objective: To provide high quality and unique experiential learning to our students which results in a real economic growth rate of $10 \%$ per annum. Indications of this growth will be demonstrated by cash flow, asset growth, innovation, environmental vitality, demand for goods and services and qualitative accomplishments. The immediate objective is wealth and job creation, and the ultimate goal is widespread middle class prosperity, social order and freedom.

The school resolutely maintained course on the above, and when the international community formalized and adopted the SDGs in 2015 there was an immediate affinity. Results to follow will include a broad range of Objectively Verifiable Indicators (OVIs) related to the SDGs (Hind et al., 2012; Makarenko, 2017; Lall, 2002). Lesotho needs the generation of strong economic growth in the range of 5-10\%/annum to correspond to necessity and aspiration (Hickel, 2020). While degrowth may be a viable option for advanced countries with declining populations and mature levels of basic infrastructure, it is not an option for Lesotho. Critics point to the high environmental costs of affluence, therefore design inspired growth, as framed by the SDGs, is attractive for its potential to beat poverty and underdevelopment without harming the planet. The credibility of the institution depends on it being a living icon... an articulated representation of the idea, with both an internal and external dimension.

Questions to be asked include: Why do we need an institution like this? What gaps are being filled? Is it important or significant? Claude Ake has pointed out the crisis of expectations demoralizing African leaders because of an over emphasis on statecraft, and an imbalance between centripetal and centrifugal development strategies (Ake, 2001). The most recent country study for Lesotho by the ADB reiterates the disparity between public and private sector led development, and the need for decentralization and market based growth and opportunity (ADB, 2020). Ake discusses the extent to which conflict and warfare distort political processes and development in Africa. In 1998, a cruel civil war broke out in Lesotho with enormous damage to commercial and institutional infrastructure. The central business districts in Maseru and Mafeteng were destroyed, burnt or looted, and half of Mohale's Hoek was razed. South Africa intervened to stabilize the situation. Since then the political climate has remained more stable, although still punctuated with unpleasant interludes which necessitated SADC and South Africa to mediate. In evolutionary terms, survival is success. In human cultural and historical terms, persistence is of interest because of the need to access and embrace new models of effectiveness (Fuller, 1987; Alexander, 1977). BBCDC possesses a broad suite of infrastructure, programs, intellectual capital and experience that is appropriate for the context in which it operates.

\section{Permaculture}

From the outset, Permaculture provided a vigorous theoretical and empirical framework for development of the school and originates with the Australian visionary Bill Mollison. Permaculture is a Meta-Science which is a fundamental advance on planning and linear thinking. Precedence is found in the writing of Buckminster Fuller, Christopher Alexander and numerous earth systems and environmental scientists (Wahl, 2016). The emergence of dense patterns through the application of design thinking is at the heart of Permaculture. The environmental educator David W. Orr has written inspiring essays and books about the elegance of design (Orr, 2000). Design means re- 
ducing the amount of space needed to sustain human civilization, and shrinking externalities of material and energy flows, while intensifying and enhancing the yield of compact and smaller spaces (Mollison, 1988). Design is visualized as a pattern of resource flows and components that reflect the stability, resilience, tenacity and diversity of natural eco-systems. Forty years ago environmental science raised the specter of the environmental footprint and a mankind characterized by thoughtless consumption and extravagance; Permaculture is a response to this malaise and articulates a handprint guided by thoughtfulness and sufficiency (as fitting for homo sapiens). SDG12 is at the core of Permaculture, namely responsibility for Earth Care, People Care, and Consumption based on comprehensive environmental assessment and accounting (Miller, 2000). The double helix of SDG12 in Figure 2 is similar to the idiosyncratic logo and cover illustration for Permaculture: A Designer's Manual.

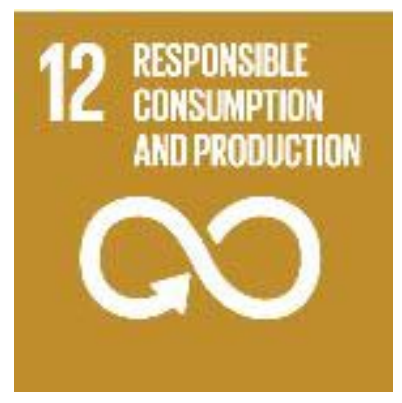

Figure 2. SDG 12.

In 1993, the 4 ha green field site was devoid of improvement. There was little vegetation, fields were degraded, and pasture land trampled and sealed. Core validity is ascribed by Permaculture to: water, energy, food and shelter. The eco-system champions of the natural world are swamps and marshes, rain forests and estuaries, reflecting an annual net primary productivity of around 9000 kilocalories $/ \mathrm{m}^{2} /$ year (Miller, 2000). Each is nutrient and water rich, and complex in species mix. By contrast, BBCDC is located in the Senqu Valley of Lesotho, a geographic region receiving an average of $600 \mathrm{~mm}$ of rain/annum. Land degradation due to overgrazing and undifferentiated land management is severe (Preston-Whyte and Tyson, 1989). Rainfall is episodic and irregular, with long periods of drought, punctuated by bouts of heavy monsoon type rainfall (Preston-Whyte \& Tyson, 1989). Lesotho falls in the summer rainfall region of Southern Africa with the long term distribution of rainfall graphically following a normalcurve with the onset of rains in September, peaking over the months of December, January and February, and then tapering off in May. The winter months are typically dry and cloudless. Table 1 below provides rainfall data for the last five years.

Table 1. Rainfall records since May, 2016 at Bethel

\begin{tabular}{ccccccccccccccc}
\hline & May & June & July & Aug & Sept & Oct & Nov & Dec & Jan & Feb & March & April & Total mm \\
\hline $2016-17$ & 46 & 0 & 0 & 0 & 11 & 8 & 62 & 11 & 68 & 168 & 10 & 0 & 384 \\
$2017-18$ & 18 & 0 & 0 & 23 & 43 & 36 & 36 & 45 & 58 & 115 & 89 & 58 & 521 \\
$2018-19$ & 24 & 0 & 17 & 62 & 8 & 6 & 0 & 52 & 46 & 149 & 166 & 80 & 610 \\
$2019-20$ & 0 & 0 & 0 & 0 & 0 & 0 & 0 & 38 & 49 & 156 & 124 & 108 & 475 \\
$2020-21$ & 0 & 0 & 7 & 0 & 26 & 33 & 87 & & & & & & 153 \\
\hline
\end{tabular}

This distribution varies significantly from long term averages and is indicative of a period of severe drought. The period from May to December 2019 was so stark that the Katse and Mohale reservoirs of the Lesotho Highlands Development Authority (LHDA) shrank to $11 \%$ and $17 \%$ respectively, and water sales to neighboring countries and electricity generation were suspended. Since January 1, 2020, BBCDC has received 590mm of rain. Without intensive landscaping and competent farming systems the result is erosion, water logging or rampant weed growth that eclipses all attempts at mechanical cultivation. By contrast, the BBCDC campus consists of natural forest and grassland, market gardens, orchards and small fields, each representing approximately $25 \%$ of the total land area, and this design framework proves to be resilient. Figure 3 illustrates the campus in 1993 and Figure 4 provides a later view from a drone in 2020. 


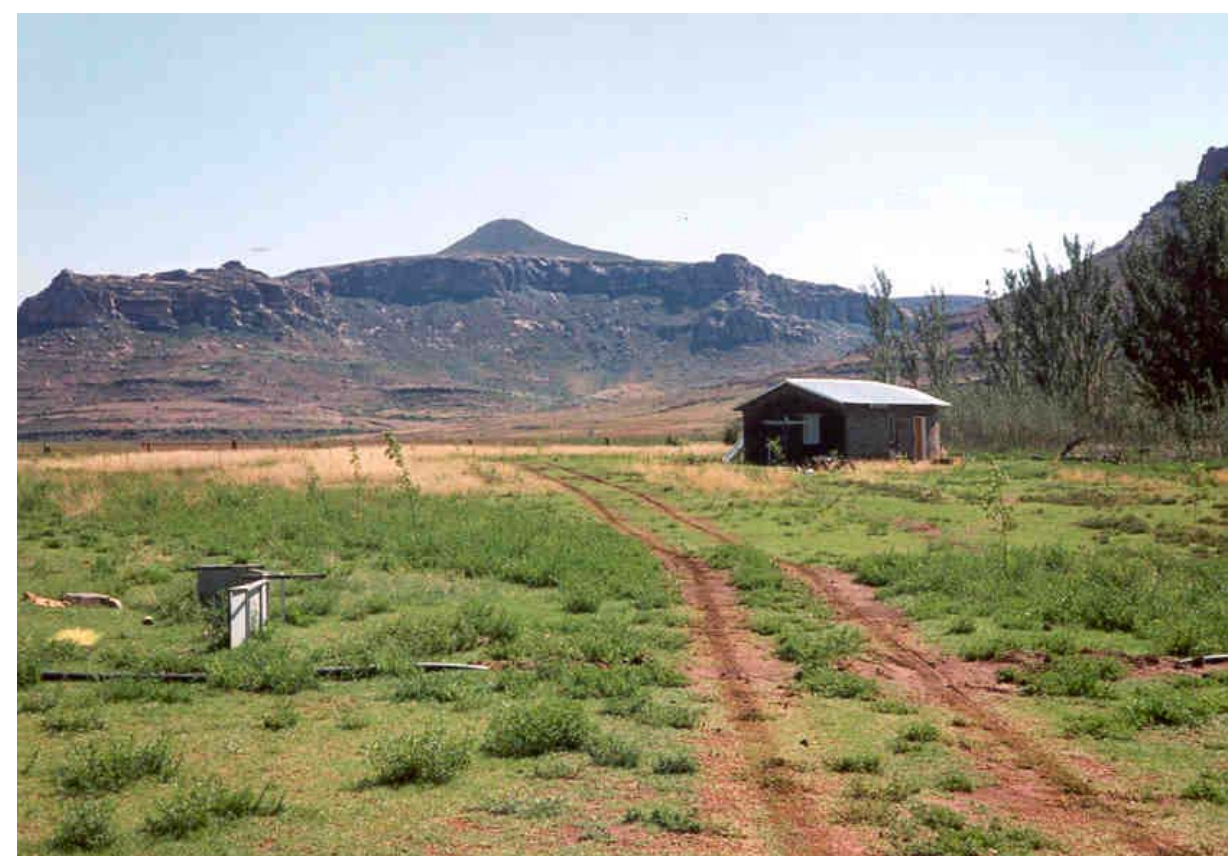

Figure 3. BBCDC campus in November, 1993 looking north from the center.

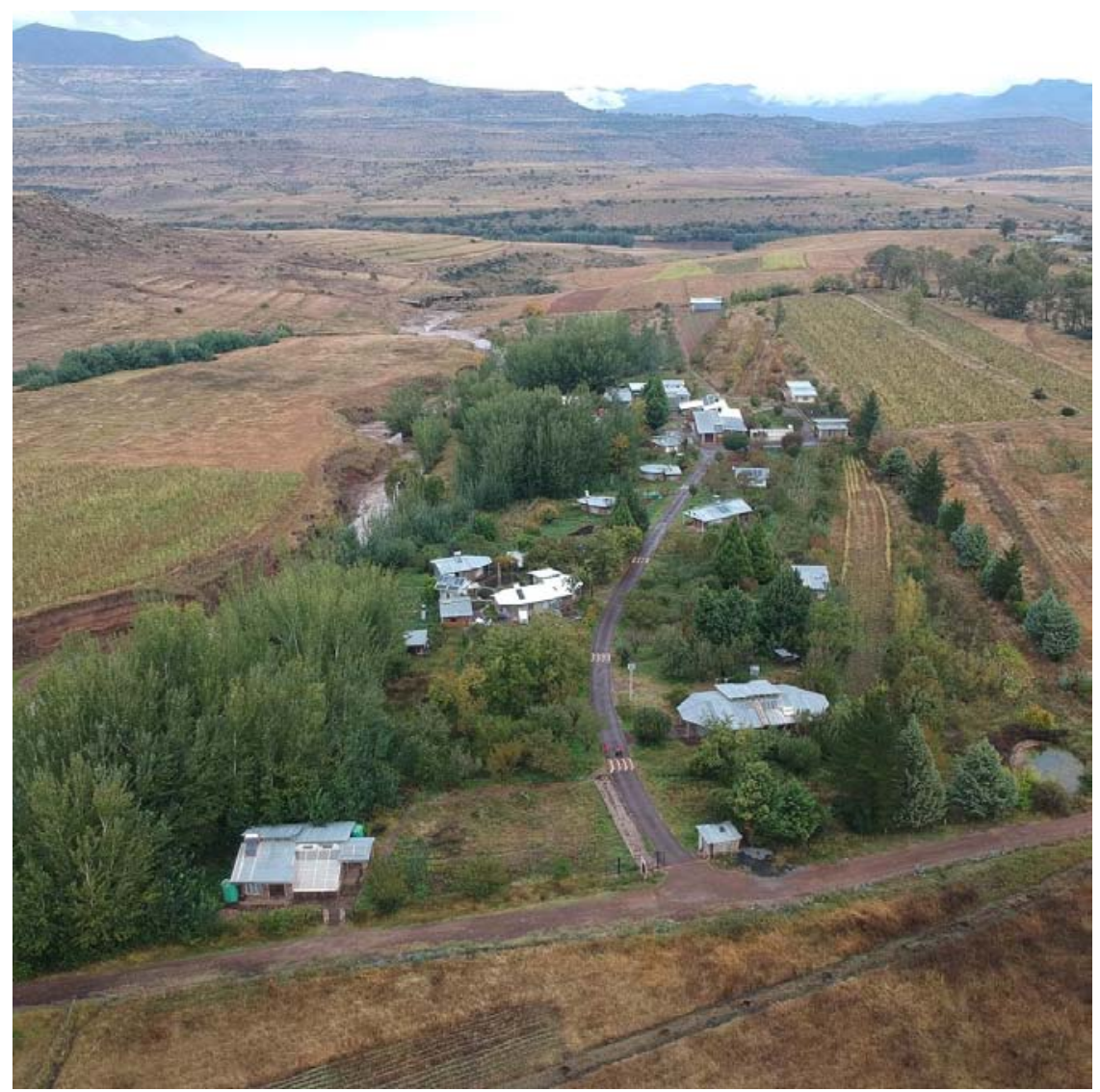

Figure 4. Drone shot of the BBCDC campus in April 2020 looking south (The dwelling in Figure 3 is center left with the white roof).

A peculiarly relevant term used in the Permaculture lexicon is the word "swale” (Mollison, 1988). Swales are excavations and earth bunds laid out along contours. They slow, spread and sink water from heavy rainfall events. 
With the aid of accurate land surveys, also a Permaculture focus, the task of digging and planting an extensive swale system on the BBCDC campus was carried out using picks and spades. With no access to earth moving equipment, this was back-breaking work because the soil was highly compacted from years of grazing by cattle and horses. The layout of the swales represented a design problem that took several years to perfect. The end result was that more water became available and water use efficiency rose, nudging up the net primary productivity of the site. Parallel to earth-working for water use efficiency, an extensive planting of mixed orchard was carried out and includes: peaches, plums, grapes, apples, apricots, pears, cherries, almonds, walnuts, olives and pecan nuts. Much of this planting is in bands along contour lines. Concurrent with this planting, small fields and market garden plots were developed, along with a vascular network of potable, irrigation and waste water. A ground water/sand dam was built in 1995 on the ephemeral stream along the eastern boundary of the campus. A few years later a well was hand dug, and these water sources were connected to multiple storage tanks and roof water collection systems. Figure 5 captures the basic landscape features that were implemented.

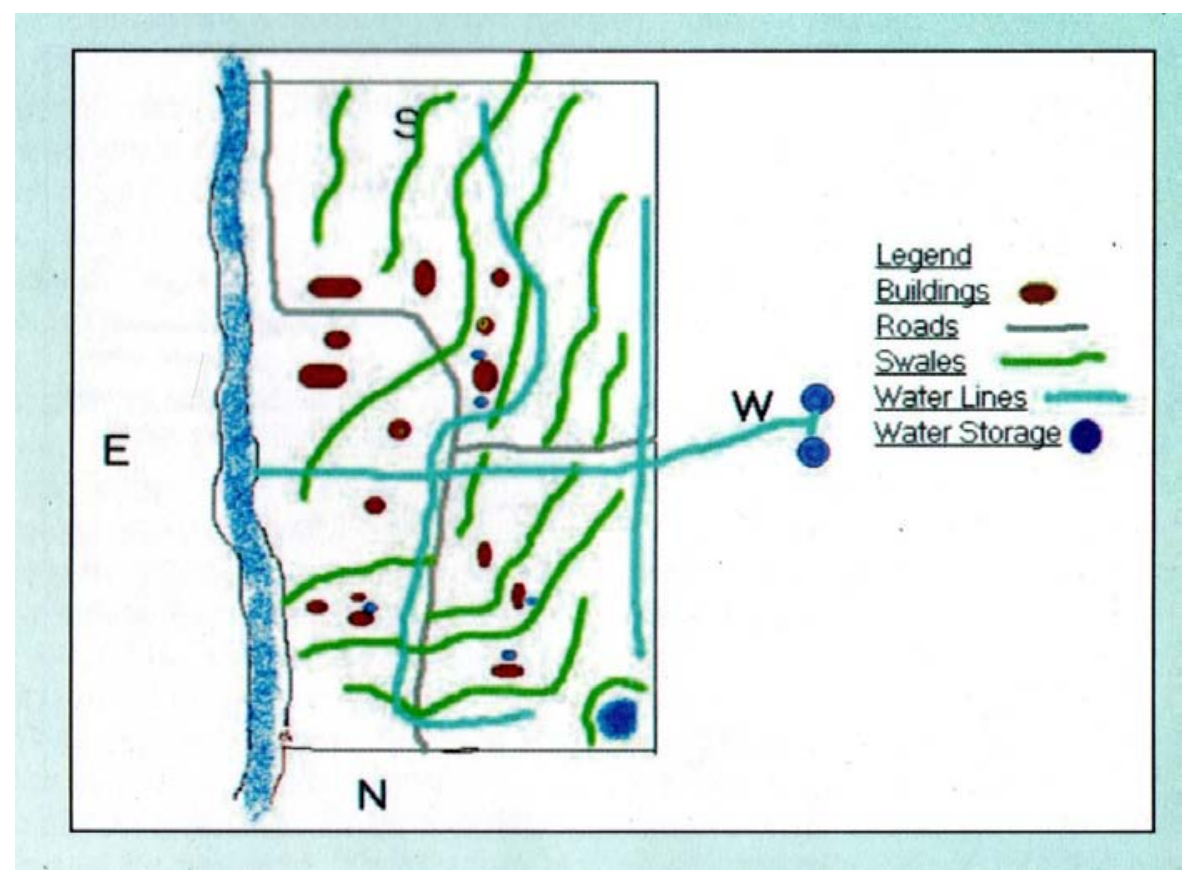

Figure 5. Map of the campus prepared in 1999.

The importance of landscaping is underlined by the following facts: water infiltrates at the rate of $11-7 \mathrm{~mm} / \mathrm{hour}$ in sands and dust, 4-1mm/hour in clay loams, and 1mm/hour in alkaline swelling clays (Mollison, 1988). Lesotho averages 7-8 high intensity rain storms per annum with intensities reaching 200mm/hour (Preston-Whyteand Tyson, 1989). Since 1999, over 100 thunderstorms have passed overhead. The swale system ensures retention of storm water, ground water recharge, and a cyclical burst of biological productivity along with steady growth of orchard and tree crops. A harmonious pattern of sun, water and life have an immediate impact on food security and basic conditions of human life as captured by SDG 1, 2, in Figure 6.

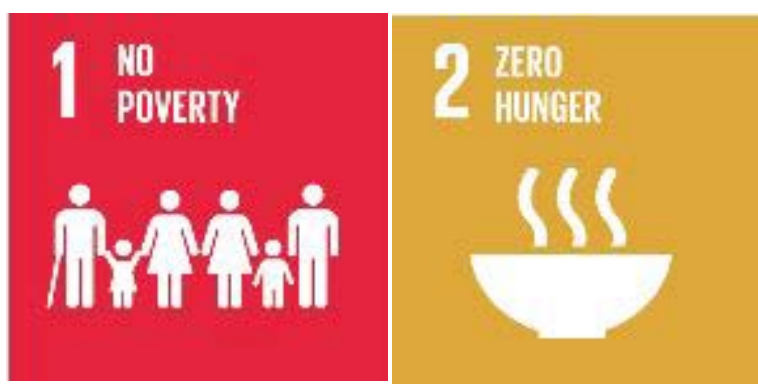

Figure 6. SDG 1, 2. 
In 2019, in response to the drought, two more ground water dams were constructed on the stream beside the campus and this, with the aid of solar powered water pumping infrastructure located at each physical site, along with irrigation piping and distribution networks, has significantly improved water availability. These three ground water dams hold back and contain a triangular wedge of approximately $3,500 \mathrm{~m}^{3}$ of coarse sand and gravel which translates into over $1,000 \mathrm{~m}^{3}$ of water in delayed storage. Without these dams in place flow would be ephemeral and sporadic. A fish and duck pond filled with water extracted from these sand dams can be seen in the bottom right hand corner of Figure 3. A useful animation of ground water dam construction and principals is available on YouTube (See also Brad Lancaster TEDx Tucson). The dams also enable cyclical sand mining for construction and other purposes. These water related activities incorporate SDGs 6, 14, and 15 referred to below in Figure 7.

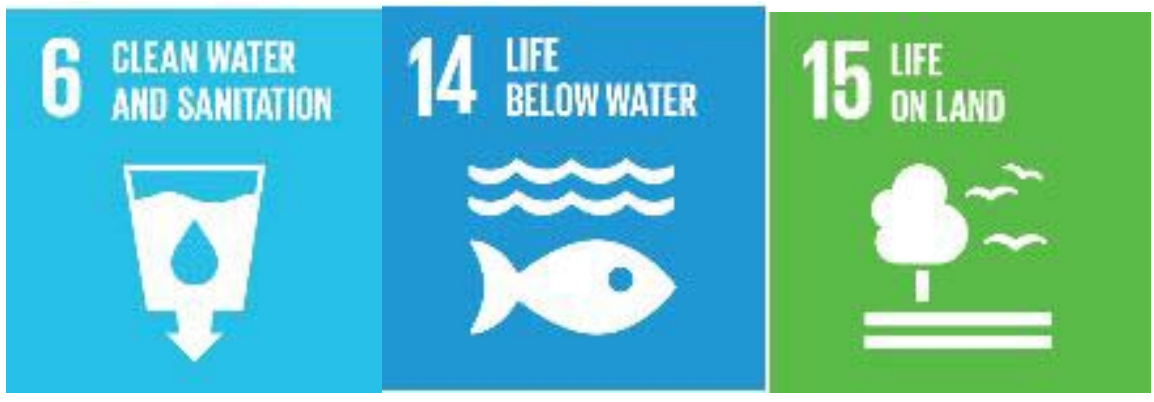

Figure 7. SDG 6, 14, 15.

Over the last decade, the term "nexus" has been used to describe the combination of water, energy and food that drives development and prosperity (OFID). While water in Lesotho is occasionally scarce and insufficient, the same cannot be said for solar energy which is another key focus for Permaculture design and patterning. Lesotho receives an average of $36 \mathrm{MJ} / \mathrm{m}^{2} /$ day of solar radiation or 300 sunny days (SADC, REN21, 2018). Photo-voltaic devices convert up to $15 \%$ of this sunlight into usable energy, while thermal devices like solar water heaters, cookers and driers achieve 70\%-90\% efficiency. The community in which BBCDC is located remains unconnected to the national electricity grid. Solar energy technology and utilization were therefore adopted through necessity. The industry has evolved considerably since then. Lesotho is short of electrical energy and imports all fossil fuels to supplement the shortfall from hydro-electricity. Peak electrical demand in Lesotho is $150 \mathrm{MW}$, with hydro-electric generation providing 75MW. Only 30\% of the nation's households are connected to the national grid (SADC, REN21, 2018). The shortfall is filled by regional power purchase agreements and service includes regular load shedding and rotating outages. During the drought in 2019, Lesotho was purchasing all of its electricity abroad (EU Special Focus, 2019).

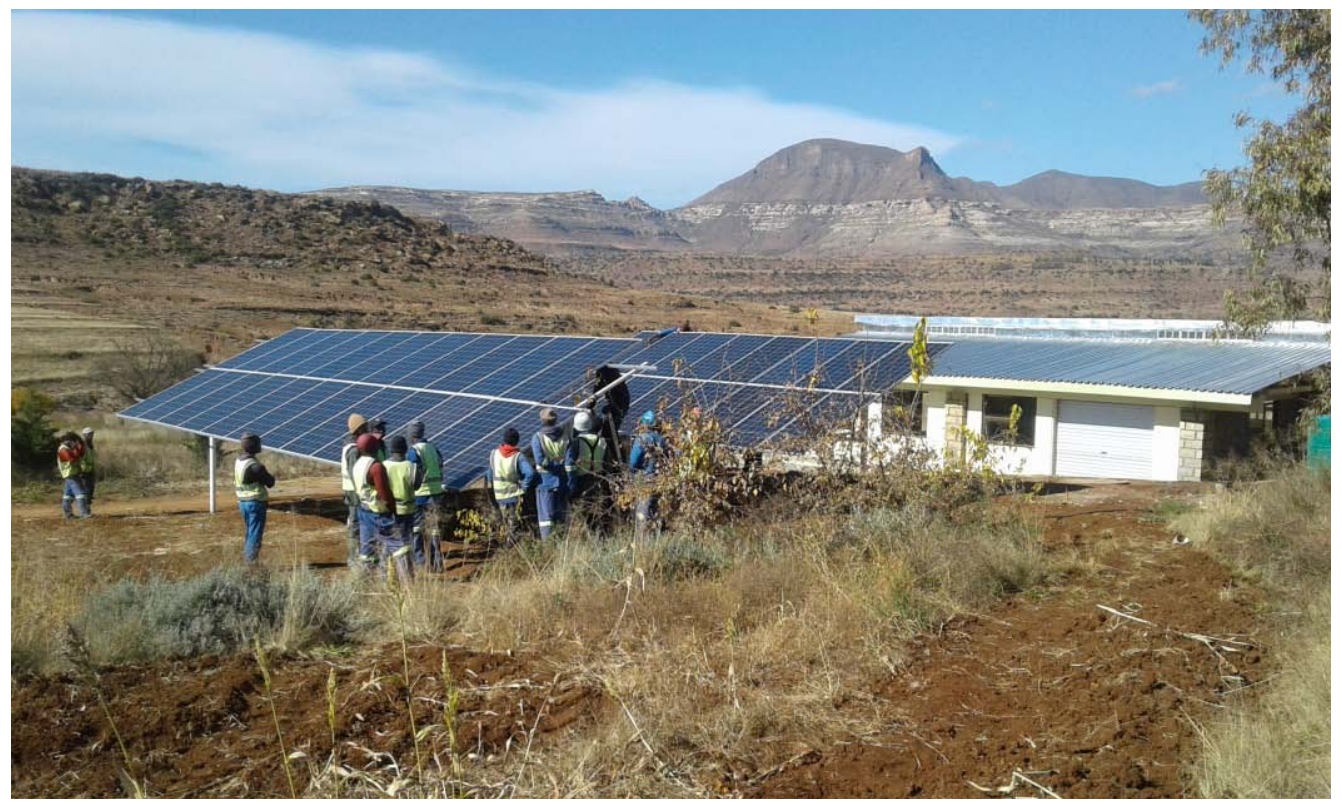

Figure 8. New Solar Lab and 16.5kW Solar Farm completed in 2019 on BBCDC campus. Balance of system includes a 10KVA sine wave inverter (230V AC) and a $20 \mathrm{kWh}$ battery storage. 
For almost two decades activities on the campus continued with numerous small stand-alone PV systems serving houses with lighting and small appliances, but these were limited. Heavy duty power for welding and the operation of shop tools required generators which were noisy and expensive to operate. About ten years ago, the solar industry began to leap forward with the price of PV panels trending rapidly down, and the range and quality of balance of systems components swiftly transformed. Today, there are five heavy duty solar power systems operating on the campus, providing power for all applications, including welding, refrigeration, kitchen appliances, computer labs, lighting, heavy duty shop equipment, and irrigation pumps. See Figure 8, all power is available as the local standard $230 \mathrm{~V}$ Alternating Current (AC). An average $150 \mathrm{kWh} /$ day of electricity is being produced. In addition, over 6,000 liters of hot water is produced by direct thermal technology each day, which translates into $330 \mathrm{kWh}$ energy equivalent. The annual value of energy produced by solar electrical and thermal power based on $\mathrm{M} 2.00 / \mathrm{kWh}$ is about M350,000.00 (M1.00 =R1.00 = \$0.059 USD, 7/6/2020).

Batteries on campus store $60 \mathrm{kWh}$ of electricity for $24 / 7$ operation. Two small wind turbines add to the power generation on campus. Innovation in the field of energy efficiency combines well with renewable and distributed energy. LED lights, flat screen monitors, and new appliances such as induction stoves and Lithium Ion powered hand tools are efficient and use less energy. Thermal systems are used extensively for water heating, cooking, space heating (passive design), cooling (solar chimneys and radiation), greenhouses (3) and day lighting.

A state of the art biogas system is in place, treating human waste and providing gas for cooking in the kitchen workshop (Figure 10). The contribution of solar and renewable energy to operations, management and the financial viability of the school is substantial and provides for high net levels of human realization and effectiveness. A vigorous solar and renewable energy focus is included in SDG 7 and 13 which are shown in Figure 9.

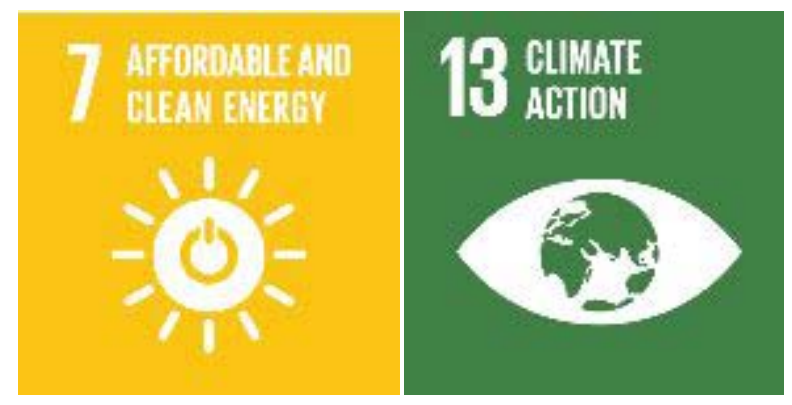

Figure 9. SDG 7, 13.

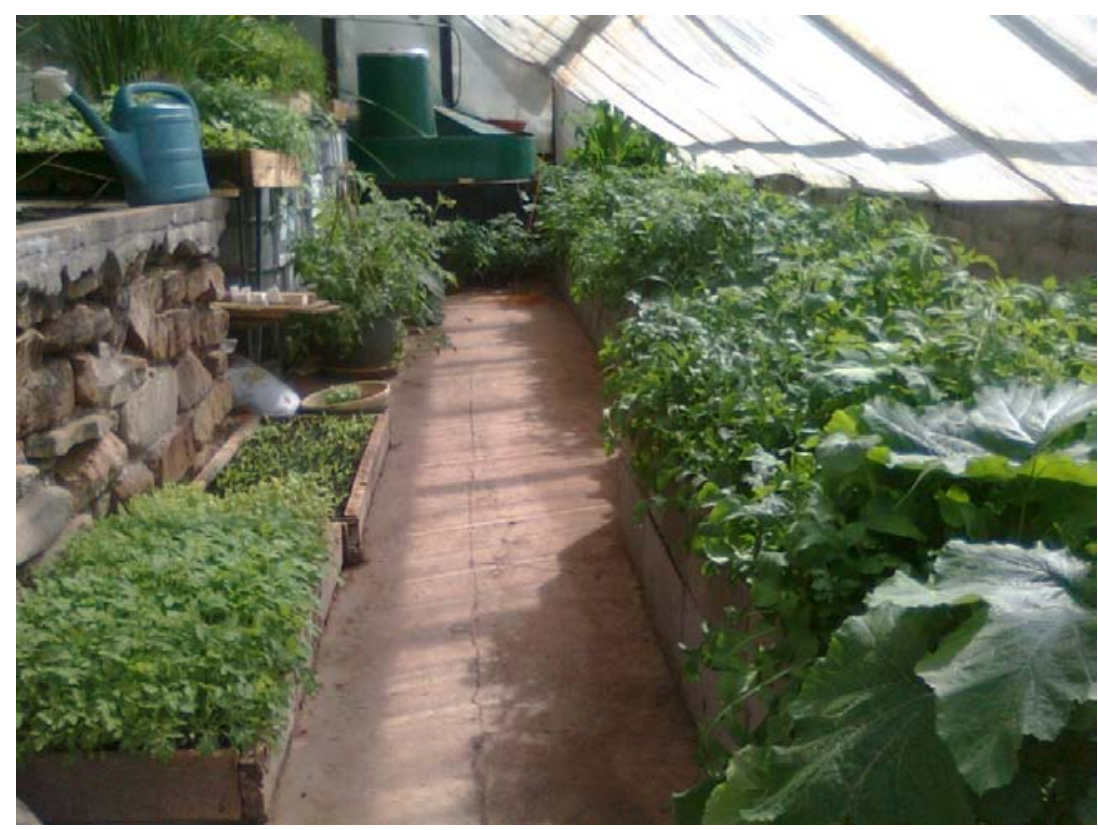

Figure 10. Biogas digester and waste water treatment system—living machine. 
Radiation science is not just a technical application but taught as central to an entire framework referred to as landscape energy quality. This means the surface geometry is analyzed to manage water and radiation balances, both subtly and substantively towards optimization.

The aim of good solar energy engineering and design in the built environment is to achieve warmer winter and cooler summer conditions, along with as much technical conversion as necessary. For example, naïve greening attempts in cities could result in the death of most trees planted in stark and undifferentiated urban canyons due to a lack of critical understanding of oasis and greenhouse effects (Lowry, 1988). By contrast, an understanding of these effects would enable an emerging earth systems science that is proactive (Oke, 1987). Water and significant vegetation density is the critical variable buffering diurnal and seasonal radiation fluxes. A porous, crumbly soil rich in nutrients and organic matter is rare in degraded agricultural landscapes. By increasing water use efficiency and applying good practices such as minimum tillage, cover cropping and green manuring, soils are much improved throughout the campus. An abundant supply of fruits and vegetables are available year round. With supplementary irrigation, cover crops like wheat and lentils grow prolifically through the Lesotho winter which means a significant boost of organic matter for soil building (Whitefield, 2004). In Permaculture, one of the primary design skills is to learn to "see" and visualize the movement of long-wave radiation through the landscape. Intricate patterns of water, soil forming, plant architecture and building geometry can optimize the quality of infrared radiation. Fundamentally, what we want to achieve are cooler summer days, and warmer winter nights. This in turn translates into greater water use efficiency, and more productive agricultural operations, along with reduced energy costs for heating or air conditioning. To summarize, water affects energy flow in the environment due to:

1) The high latent heat capacity of water: $2.45 \mathrm{MJ} / \mathrm{kg}$.

2) The high heat density of water: $4.186 \mathrm{MJ} / \mathrm{m}^{3} /{ }^{\circ} \mathrm{C}$.

3) The high heat capacity of wet soils (more than two times as great as dry soil).

4) The high thermal conductivity of wet soils (6-7 times as great as dry soil).

5) The high thermal storage capacity of living plants, especially in the case of trees and forested areas, due to the enormous water volume they bear.

6) The physical characteristic of water bodies is such that visible light is able to penetrate to considerable depth.

7) The fact that water vapor in the air slows radiative cooling after sunset (Oke, 1987).

Because of enhanced water availability on campus, carbon fertilization, and thus food cultivation is significantly enhanced. Mention also needs to be made that due to the lopsided weather conditions there is an implied acute fire risk as rampant growth accumulates combustibles during the monsoon phase. This fuels fire-storm conditions during the drought phase. Imbuing a landscape with fire-resistance and restoration is a pressing and complex task in arid environments (Mollison, 1988).

Shelter is another collective term given precedence in Permaculture. All structures on the campus have been constructed by students and staff through experiential learning, and now number 28 major buildings. These include residential dormitories for female students, staff housing, guest housing, workshops, classrooms, greenhouses, kitchens and ablution facilities. Design thinking permeates the built environment. Each situation is unique and requires consideration of the building envelope as an optimal active space, surface and location. If we fail in this task, the likely result is some form of pollution, flooding, and high energy inputs to circumvent overheating or cold (Mollison, 1988). A permaculture design lens requires that an element be thoroughly analyzed. To festoon roof tops and buildings with photo-voltaic panels along with vast tracts of land is an example. While renewable energy technology is an undoubtedly good, concentration and homogenization of the element (PV panels) makes it act as a pollutant in some regards, like a road that is wider than necessary or a parking lot without any trees or storm water retention. Good design balances many elements and allows them to function as an integrated system. The utility of each particular element is not the question, but whether the pattern they make operates synergistically. Agro-photovoltaics is an emerging practice, where PV, plants and animals, and water collection mesh together.

Structures typically include ceiling insulation, day-lighting, rainwater harvesting systems and careful solar orientation, together with roof geometry conducive to solar energy applications. Five solar chimneys are used to passively ventilate kitchens and workshops. A central lane and plaza has been paved with a bitumen and stone chip seal, developed and installed by the school itself as a research and development initiative (South African National Roads Agency, 2007). This obviates dust and mud, the bane of typical underdeveloped rural or slum urban conditions, and adds significantly to the creation of a public-realm campus encouraging student interaction. See Figure 11, the road is raised as part of an intricate storm water management and collection system. The paving was done quickly and 
for modest cost (M50.00/ $\mathrm{m}^{2}$ which is $25 \%$ of the cost for in-situ concrete or concrete brick paving).

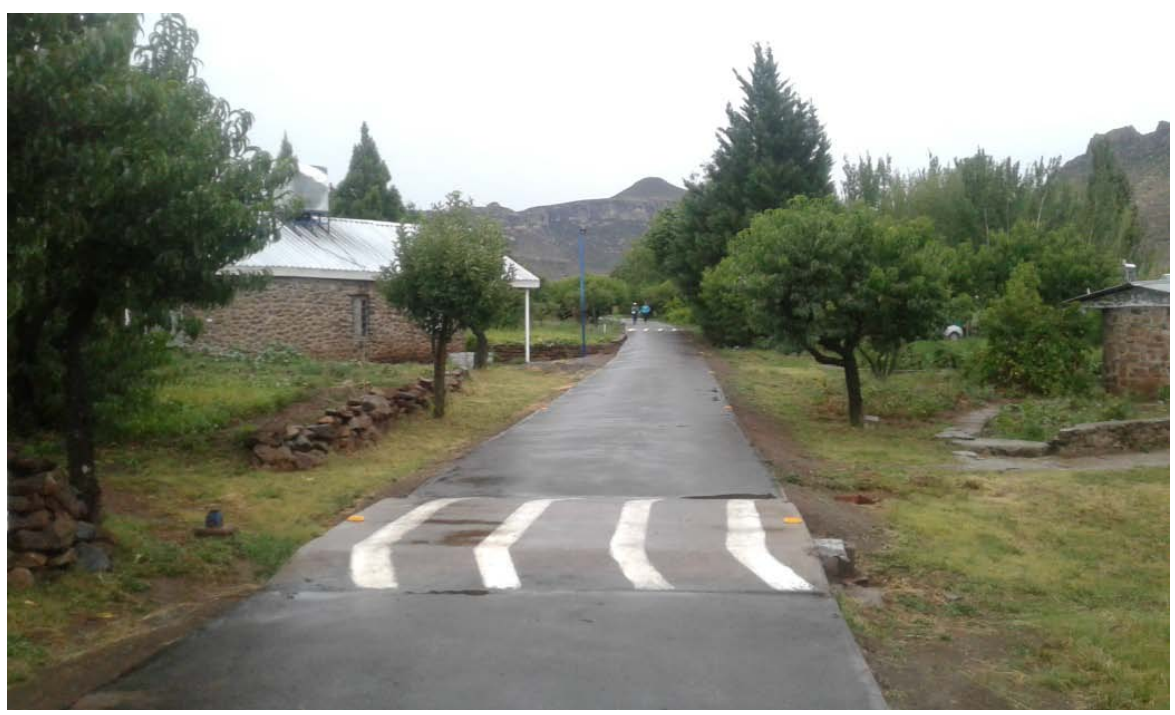

Figure 11. Paved lane through the BBCDC campus with four speed bumps/water management features.

Lesotho is rocky, with abundant natural outcroppings of sandstone, dolerite and basalt. Boulders, sand and gravel are widely dispersed and available. Natural stone was used extensively for all of the buildings and as mass footing and foundation material to reduce the need for concrete and cement. While it took several years to complete, an integrated waste water treatment and recycling system has been installed as shown in Figure 10. This includes flush toilets for male and female students, a biogas digester and living machine located inside a large greenhouse, a tank for treated waste water, and a set of intensive market gardens (Austen, 2002). The natural fall of the land is used to move waste without energy. Biogas is a valuable byproduct and nutrients are recycled and replaced at the top of a food web in a compact, energy efficient, and productive cycle. The only recurrent energy input required is an electric sump pump that runs automatically for a few minutes each day.

A design question posed by new urbanism is the need to determine an appropriate level of density. There needs to be sufficient porosity retained in the built environment to grow food, infiltrate and store rainwater, collect energy and assimilate and recycle wastes. The campus is porous. Mature tree canopies now provide shade in the right place, while conifers are situated strategically to provide a vertical edge for winter solar gain at low sun angles. The roof area of structures comprises $5 \%$ of the entire area of the campus. Roads, paths and plazas account for another $5 \%$ of sealed surface, leaving $90 \%$ of the space for growth and storm water retention.

\section{Education}

The second main theme discussed is innovation for education. The first section surveyed the implementation of Permaculture Design on the campus. This section concerns itself with education for design and the matching skills set. It contrasts to specialized career/urban job sets and instead is purposely multi-disciplinary for good reason (World Bank/UNDP, 2020). In 1998, the Lesotho National Development Corporation (LNDC) constructed an industrial zone in Mohale's Hoek of factory shells. They remain empty to this day. In parallel, the WB supported development of a ceramic tile factory in Mafeteng. It went bust soon after beginning and remains a hulking reminder of failed industrialization. BBCDC devised a program of practical education and skills required for rural and urban development and fostering of commercial enterprise on a decentralized basis. The two year residential course is open to young Basotho men and women. Education is "hands-on" with focus on self- reliance and income generation. The guiding theme of learning is experiential education which is outcomes based (Rimkus \& Lauzon, 2003). Exit level outcomes for graduates include three broad capacities: business sense, employment potential and skills for self-reliance. Such generalists are employable, capable of incubating and operating micro-enterprises, and capable of practicing resourcefulness and operational independence. A number of follow-up tracer studies have been conducted and these indicate that the program offered by BBCDC works. Graduates are getting jobs, becoming entrepreneurs and starting small businesses. The demand for entry to the school would cease if this was not the case. 170 students are registered to begin a new two year session in July 2020. The programs elicit sensory and multiple intelligence, resulting in the 
emergence of self-confidence and optimism (Jaeger, 1967).

All courses are inclusive and Co-ed. Theoretical lessons are paced with time spent on real income generation or infrastructure projects. Students are allowed to customize their interests and choose any four subjects from the list below:

- Solar Technology.

- Building Construction.

- $\quad$ Metal-work.

- Wood- work.

- $\quad$ Food Science and Culinary Arts.

- Environmental Science.

- $\quad$ Business Development and Management, Personal Effectiveness and IT.

- Travel, Tourism, Eco-tourism and Leisure.

First year, topics and activities provide foundations for the second year. Time is allocated for individual projects. Students are assessed according to their skills, knowledge and experience. Special emphasis is placed on SMME development in all courses. Upon completion of the two years, students are awarded a Certificate of Applied Science and Technology. In 1993, BBCDC began with 10 students and 4 permanent staff. In 2019, the student roll is over 250, and for the first time, the school admitted equal numbers of male and female students into the first year. There are now 18 full time staff members. Gender no longer attracts entry to specific courses as it once did. Demand for admission is rising each year and the school has expanded. In 2019, BBCDC admitted 150 first year students and turned away 100 applicants due to lack of capacity.

Table 2. Graduates

\begin{tabular}{ccccccccccccc}
\hline Year & 2010 & 2011 & 2012 & 2013 & 2014 & 2015 & 2016 & 2017 & 2018 & 2019 & 2020 \\
\hline Male & 19 & 22 & 14 & 1 & 17 & 15 & 18 & 36 & 63 & 93 & 103 \\
Female & 13 & 8 & 6 & 2 & 16 & 5 & 9 & 20 & 26 & 40 & 40 & \\
Total & 32 & 30 & 20 & 3 & 33 & 20 & 27 & 56 & 89 & 133 & 143 & 586 \\
\hline
\end{tabular}

Students that enter BBCDC are typically early school leavers, dropouts, or have completed various levels of education with a poor exit result (Lesotho, Education Statistics, 2014). Early support and encouragement from UNICEF was due to the funnel like nature of the formal school system in Lesotho, and the lack of practical and survival skills being taught (Figure 12). More than 25 years since inception, this general situation is little changed.

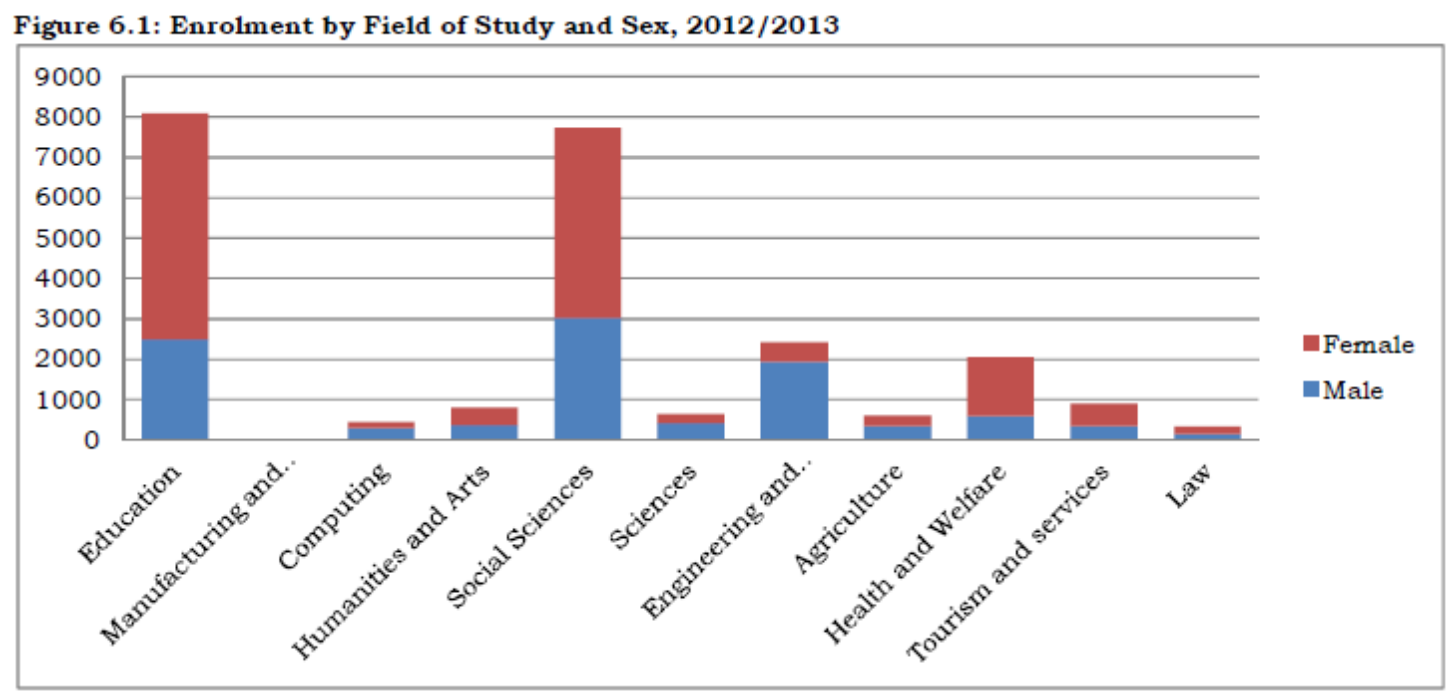

Figure 12. Enrolment in tertiary education in Lesotho.

More options for vocational type education are available. Students are not subject to a failure category; they graduate with a level 1, 2 or 3 designation for each subject as long as them meet residency requirements and partic- 
ipate. This is sufficient differentiation. Over the two years, students engage with a broad range of technologies, tools, materials and processes. Science Technology Engineering and Mathematics (STEM) education permeates the curriculum and daily activities. The outcome is adaptable and flexible individuals, with a basis to discover their likes and dislikes, natural aptitudes and talents. This approach is relatively rich in opportunities.

Education for design is a reflexive combination of relationships, reach and impact. To summarize:

Design: Is assembling systems that provide for human needs efficiently and conscientiously, and pursuing constant evolution.

\section{- Relationships:}

- $\quad$ Basic environmental science: energy and matter transfer pathways of nature.

- $\quad$ Radiation, hydrology, biology, geo-morphology, nutrient cycling.

- Human technology and materials science.

- Commercial and environmental opportunity.

- Motivation and aspiration.

- Reach:

- Acquisition of skills, know-how and self-confidence through experiential learning.

- $\quad$ Problem solving.

- $\quad$ Sensory and multiple intelligence.

- $\quad$ Projects employing, tools, equipment and materials.

- Income generation.

- Research and development.

- Formation of new social capital.

- Impact:

- Paying your own way.

- Gaining traction in the market place.

- $\quad$ Producing results.

- $\quad$ Investment in new infrastructure.

- Work and employment.

- Generating new knowledge and innovation.

The education program embraces SDGs 3, 4, and 5 as seen in Figure 13. As a progressive institution concerted efforts to mainstream gender issues were implemented since inception.
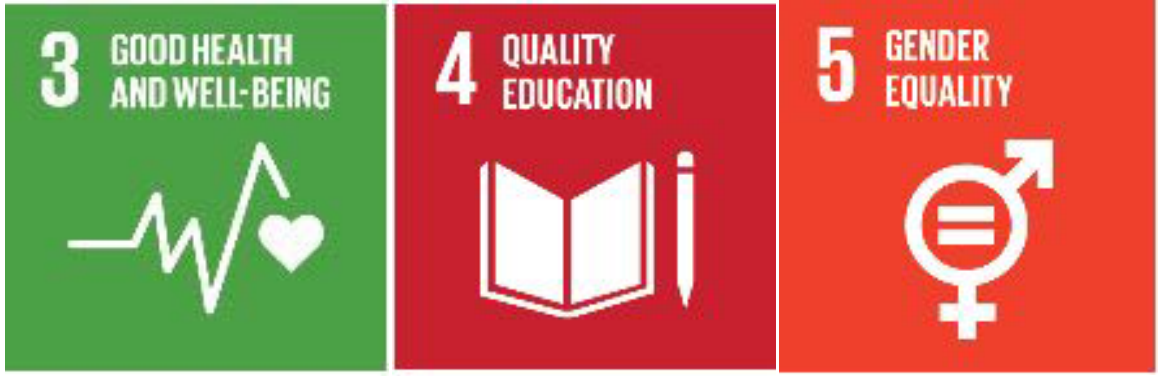

Figure 13. SDGs 3, 4, 5.

\section{Enterprise}

The third theme discussed is the role of enterprise which underpinned the financial viability of the institution and enabled it to grow and invest in itself. What distinguished the SDGs from earlier sustainable development initiatives is recognition of a much greater role for business and decentralization, and recognition of the limits and pitfalls of politics and over institutionalization (Bebbington, 2018). Lesotho is replete with failed development projects. The country and development agencies learned painful lessons about what constitutes moral hazard, and the implications of supply-push social engineering (Ellerman, 2002). Without enterprise and a financially self-sustainability strategy, development organizations are in the precarious position of being perpetual supplicants (Hayek, 1944; Easterly, 2006). BBCDC strove from day one to pay its own way and operate as both an enterprise and an institution. In a resource scarce situation, BBCDC derived value from its location through efficient design and by pursuing economic opportunity. The option of remaining a "non-profit" organization, soliciting subventions to cover all operating costs 
year after year, was not viable. Enterprise is a more far reaching term than entrepreneurship, and usually encompasses pioneering, frontiers and substantive problem solving.

In 1997, a small lodge was constructed on campus to be let for travelers and guests; in 2000, a commercial kitchen and dining room was added, and another structure renovated to provide more guest rooms. This operation provided a remarkably steady income and an enormous range of practical experience for the food science and culinary arts program.

In 2000, experience gained from the practical application of solar technology on the campus was used to start a solar business. A trademark: "Solarsoft" was registered, inspired by the work of Amory Lovins who used the term "soft energy paths" for decarbonization and weaning from fossil fuels (Hawken, Lovins, \& Lovins, 1999). Marketing and branding efforts are illustrated in Figure 15. BBCDC also capitalized on its construction experience by working on projects throughout Lesotho. Collectively, the guest lodge, solar sales division and construction capacity now provide significant cash flow. Since 2016, Solarsoft has imported three containers of solar water heaters from China, and is expecting a $4^{\text {th }}$ container to arrive by the end of November 2020. International finance, shipping and logistics is now part of its forte.

The school is serious about its corporate social responsibility and maintains a high degree of focus on achieving best practices for governance and operation. The school is managed by a constituted Board as required by the Education Act of Lesotho, and meets 4 or more times each year. An Annual Review is published and distributed annually. Operations include filing corporate income tax on commercial operations, VAT registration, a current tax clearance certificate, business and hotel license and annual audit by an accounting firm. Tax remittances to government accounts in Lesotho total over M1,000,000.00 for the last ten years.

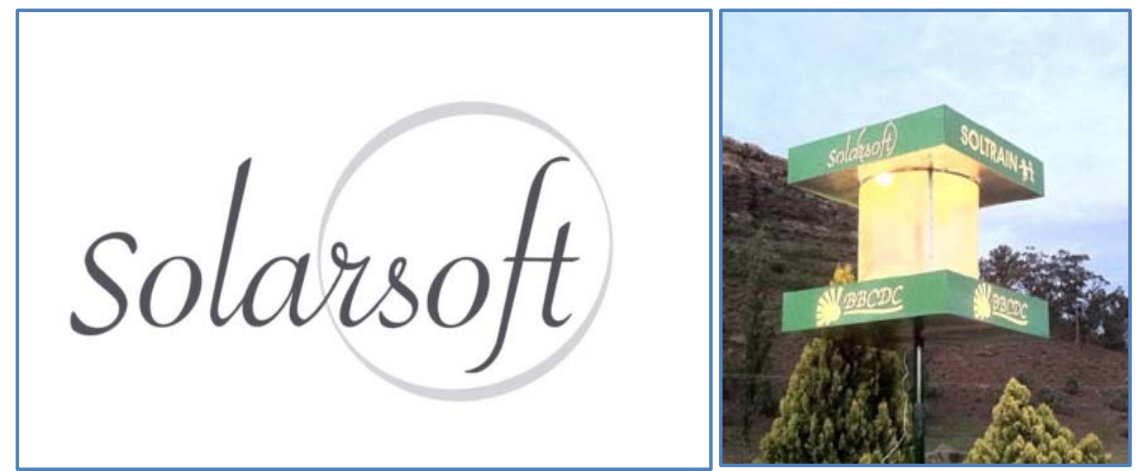

Figure 14. Registered trademark for solar energy enterprise; Green Lantern, Mohale’s Hoek.

Students cannot afford high tuition fees and there is limited tax payer support. Staff and students partner to work together; operations generate revenues that sustain the school and provide the students with real world experiential learning. Renovation and new construction is routinely financed from retained earnings. It is a strategy that works and is appropriate in this context. Students are often paid for attachments and special projects, and this enables them to share in commercial success (See Table 3 and Figure 15). The school is registered with the Ministry of Education and Training, which provides salaries for four qualified teachers. Presently 14 other employees are paid by the school including 5 additional teachers.

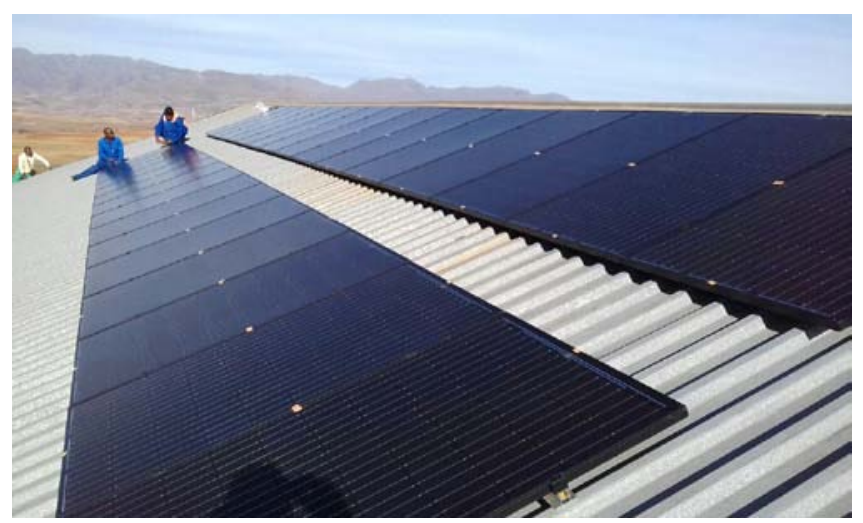

Figure 15. PV Array installed at Malealea Lodge in August 2016. 
Over the last 27 years, operations have created a fully developed educational campus on its home grounds, and carried out significant works throughout Lesotho.

\section{Table 3. Person Month Paid Employment (PMPE)}

\begin{tabular}{|c|c|c|c|}
\hline Year & On Campus & Off Campus & Remarks \\
\hline 1993 & $\begin{array}{l}\text { Construction of original workshop and one } \\
\text { staff house. }\end{array}$ & & \\
\hline 1994-1999 & & $\begin{array}{l}\text { Construction of } 11 \mathrm{~km} \text { of local feeder road } \\
\text { with the World Food Program. }\end{array}$ & $\begin{array}{l}\text { Labour based methods } \\
100 \text { people/month. }\end{array}$ \\
\hline 1995 & Construction of two staff houses. & $\begin{array}{l}\text { Construction of four staff houses at Mase- } \\
\text { ribane High School. }\end{array}$ & $\begin{array}{l}\text { Student attachment: } 60 \\
\text { PMPE }\end{array}$ \\
\hline 1996 & Construction of two classrooms. & & \\
\hline 1997 & Construction of guest facility/lodge. & & \\
\hline 1998 & Construction of two staff houses. & & \\
\hline 1999 & & $\begin{array}{l}\text { Construction of stone ford across Senqu } \\
\text { River. }\end{array}$ & $\begin{array}{l}\text { Enabled seasonal crossing } \\
\text { 2-6 months/year. }\end{array}$ \\
\hline 1999-2016 & & Repair of stone ford each winter. & \\
\hline 2000 & $\begin{array}{l}\text { Construction of administrative centre, } \\
\text { visitors' dining room and commercial } \\
\text { kitchen. }\end{array}$ & $\begin{array}{l}\text { Construction of office and two staff houses } \\
\text { for Solarsoft in MohalesHoek. }\end{array}$ & $\begin{array}{l}\text { Student attachment: } 36 \\
\text { PMPE }\end{array}$ \\
\hline 2001 & $\begin{array}{l}\text { Construction of classroom and students' } \\
\text { kitchen. }\end{array}$ & $\begin{array}{l}\text { Construction of passive solar demonstra- } \\
\text { tion house in Zastron, RSA. }\end{array}$ & $\begin{array}{l}\text { Student attachment: } 36 \\
\text { PMPE }\end{array}$ \\
\hline 2002 & & & \\
\hline 2003 & $\begin{array}{l}\text { Construction of classroom and green- } \\
\text { house. }\end{array}$ & & \\
\hline \multicolumn{4}{|l|}{$\begin{array}{l}2004 \\
2005 \\
2006\end{array}$} \\
\hline 2007-2012 & & $\begin{array}{l}\text { Construction at Storm Mountain Diamond } \\
\text { Mine. }\end{array}$ & $\begin{array}{l}40 \text { major structures. } \\
\text { Student attachment: } 300 \\
\text { PMPE }\end{array}$ \\
\hline 2008 & $\begin{array}{l}\text { Greenhouse, biogas and waste water } \\
\text { treatment system. }\end{array}$ & $\begin{array}{l}\text { Two rental properties at Solarsoft in Mo- } \\
\text { halesHoek. }\end{array}$ & $\begin{array}{l}\text { Student attachment: } 40 \\
\text { PMPE }\end{array}$ \\
\hline 2009 & Construction of staff house. & & \\
\hline 2010 & Construction of staff house. & & \\
\hline 2011 & Construction of house. & & \\
\hline 2012-2014 & $\begin{array}{l}\text { Construction of Learning Centre: four labs } \\
\text { and student centre. }\end{array}$ & & \\
\hline 2013 & Construction of ablution blocks. & & \\
\hline 2014 & Tracking solar arrays and solar micro grid. & $\begin{array}{l}\text { Construction of orphaned childrens' home } \\
\text { in MohalesHoek. }\end{array}$ & $\begin{array}{l}\text { Student attachment: } 120 \\
\text { PMPE }\end{array}$ \\
\hline 2015 & Construction of house with rotating roof. & & \\
\hline 2016 & & $\begin{array}{l}\text { Installation of solar mini grid for } 55 \text { room } \\
\text { lodge at Malealea; water supply. }\end{array}$ & $\begin{array}{l}\text { Student attachment: } 24 \\
\text { PMPE }\end{array}$ \\
\hline 2017 & & $\begin{array}{l}\text { Construction of two private houses in } \\
\text { Alwynskop. }\end{array}$ & $\begin{array}{l}\text { Student attachment: } 150 \\
\text { PMPE }\end{array}$ \\
\hline 2018 & $\begin{array}{l}\text { Construction of IT Lab. Paving of lanes. } \\
\text { Bitumen paving of lanes and courtyard. }\end{array}$ & $\begin{array}{l}\text { Extension of warehouse/workshop at So- } \\
\text { larsoft. }\end{array}$ & $\begin{array}{l}\text { Student attachment: } 30 \\
\text { PMPE }\end{array}$ \\
\hline 2019 & $\begin{array}{l}\text { Construction of Solar Lab and } 16.5 \mathrm{~kW} \\
\text { solar farm. } \\
\text { Construction of two sand dams. }\end{array}$ & $\begin{array}{l}\text { Construction of sand dam and solar po- } \\
\text { wered water supply Baluma Tau. }\end{array}$ & $\begin{array}{l}\text { Student attachment: } \\
\text { PMPE }\end{array}$ \\
\hline 2020 & Construction of two guest flats. & $\begin{array}{l}\text { Construction of sand dam and solar po- } \\
\text { wered water supply Ha Patsa. }\end{array}$ & $\begin{array}{l}\text { Student attachment: } 25 \\
\text { PMPE }\end{array}$ \\
\hline
\end{tabular}

Activities and Results Summary: 1993-2020 
Economic diversification and technical innovation include the following: developing and perfecting a modular column and box beam building system used to construct 10 major structures; experience with biogas using readily available and low cost plastic vessels; a variety of solar cooking devices; a rotating roof for a solar PV micro-grid and low-cost rotating solar trackers; 5 ground water/sand dams; 9 of the full time employees are female and 8 are male. For more than 20 years, gender balance is specified for remote work crews. Decentralized economic growth and accomplishment broadly fits within the ambit of SDGs 8, 9, 10, and 11 shown in Figure 16.
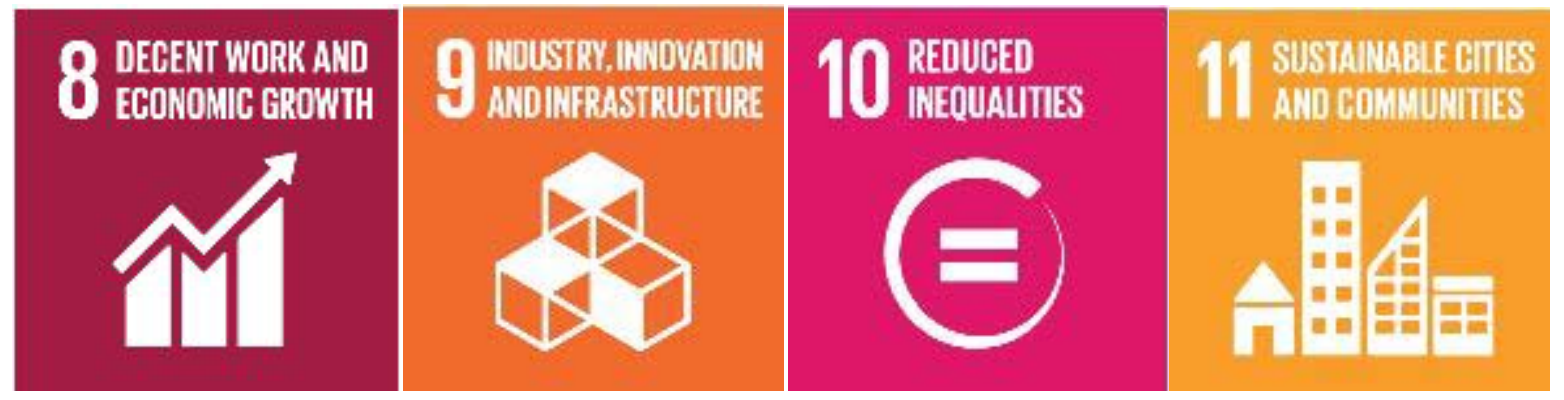

Figure 16. SDGs 8, 9, 10, 11.

Additional evidence of outreach and impact includes the following:

- 21 international and regional interns pursued studies at BBCDC (Table 4).

- $\quad$ List of Interns at BBCDC: 1994-2020.

Table 4. Matt Orosz, Leah Samberg, Timothy O’Connell and Moipone Letsie went on to obtain a PhD. Sasha Rimerez-Hughes works for IRENA. Matt Orosz founded Onepower which is building a 20MW solar farm in Lesotho

\begin{tabular}{|c|c|c|c|c|c|}
\hline Year & Name & Gender & Months & Country & Affiliation \\
\hline 1994 & Mark Himsworth & M & 6 & Great Britain & Personal \\
\hline 1995 & Steve Lapp & M & 4 & Canada & BRI \\
\hline 1996 & Sasha Remirez Hughes & M & 6 & Canada & BRI \\
\hline 1996 & Trevor Sims & M & 6 & Canada & WUSC \\
\hline 1997 & Christian Robert DeMassy & M & 6 & Canada & $\mathrm{BRI} / \mathrm{UBC}$ \\
\hline 1998 & Vadim Belotserkovsky & M & 6 & Canada & BRI \\
\hline 1999 & MoiponeLetsie & $\mathrm{F}$ & 3 & Lesotho & NUL \\
\hline 2000 & Andrew Watkins & M & 18 & USA & USPC \\
\hline 2002 & Jean Brokish & $\mathrm{F}$ & 12 & USA & USPC \\
\hline 2002 & Ben Schmidt & M & 12 & USA & USPC \\
\hline 2003 & Doug Hannah & M & 3 & USA & Dartmouth U \\
\hline 2004 & Leah Samberg & $\mathrm{F}$ & 3 & USA & Dartmouth U \\
\hline 2004 & Matt Orosz & M & 9 & USA & MIT \\
\hline 2005 & Amelia Potvin & $\mathrm{F}$ & 3 & USA & Dartmouth U \\
\hline 2006 & Will Fort & M & 3 & USA & Dartmouth U \\
\hline 2007 & Diana Jih & $\mathrm{F}$ & 3 & USA & Dartmouth U \\
\hline $2007-2008$ & Kjessie Rubke & $\mathrm{F}$ & 20 & USA & USPC \\
\hline 2008 & Timothy O’Connell & M & 12 & USA & USPC \\
\hline 2014 & Stephen Beale & M & 3 & Canada & Personal \\
\hline 2016 & Timothy Cronje & M & 12 & South Africa & Personal \\
\hline 2017 & Malte Schien & M & 6 & Germany & Brunswick U \\
\hline 2019 & Teboho Mohale & M & 3 & Lesotho & LerotholiPolytech \\
\hline 2020 & Zachariah Moeketsi & M & 6 & Lesotho & College of Agriculture \\
\hline
\end{tabular}


- The school received Energy Globe Awards for Lesotho in 2015, 2016, and 2017, along with an Emirates Energy Award in 2017 that included a cash prize of 21,760.00USD.

- In 2019, a private group in Europe provided an unsolicited award of 20,000.00 Euro in recognition of leadership in solar energy development.

- In 2000, the late Dr. Mabia Moletsane, former Vice Chancellor of the National University of Lesotho, formed a partnership to replicate the school in his home village of Liphiring. It remains in operation as the Taung Skills Training Centre and is also a registered TVET school in Lesotho.

- The school has presented results and papers at numerous international and regional conferences, forums and media platforms. As Lesotho as a nation gets on its feet and addresses problems of a different nature and scale, local efforts complement these.

- $\quad$ BBCDC is the lead partner for the Soltrain Project in Lesotho. Soltrain II ran from 2014-2016 and the third phase of Soltrain III from 2016 -2018. The partnership continues for Soltrain IV which will run until Dec. 2022. Soltrain provides professional training and business incubation for solar thermal applications and processes ranging from household to industrial scales. It is a joint undertaking of BBCDC in Lesotho, AEE-Intec, the Austrian Development Agency, and the OPEC Fund for International Development (OFID). OFID is providing project funds for installation of demonstration solar thermal systems at social institutions: clinics, schools, group homes and facilities for travellers (Soltrain, 2019).

- Solarsoft provides guest lectures, study tours and field schools for NUL's MSc. In Renewable Energy since the program began in 2017.

Glen Paoletto summarizes the mosaic trend of institutionalization in this way:

- Customization instead of standardization.

- Synchronization over just-in-time production.

- Holistic approaches over specialization.

- Flat organizational charts replacing centralization.

- A move away from central authority (Paoletto, 1999).

BBCDC's long record of collaboration with numerous development agencies together with an emphasis on good governance is captured by SDGs 16 and 17 (Figure 17).

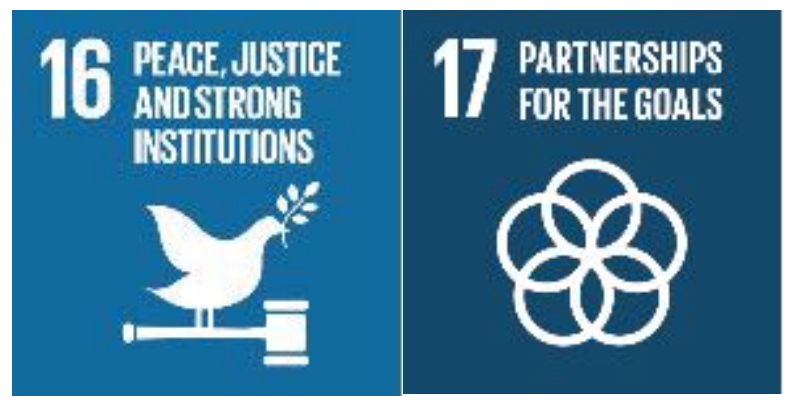

Figure 17. SDGs 16, 17.

Lesotho is a small country with a population of approximately 2 million people. This startup launched without much fanfare or central planning. The school now has impact throughout Lesotho, both through operations and dispersal of graduates. Core activities embrace the central tenets of sustainable development. Planetary stress necessitates multi-disciplinary innovation. In writing this paper we are disseminating results and demonstrating what is possible. The WCED and the SDGs provide a valid pattern for the future and much succor for circumstances in Lesotho. Emergence, survival and success are not a smooth, calm or inherently orderly process, but are often gritty, chaotic, demanding and uncertain.

\section{Lessons Learned}

Operations have experienced significant trials and a number of these are summarized below:

- Education is universally fraught with disciplinary issues and deep emotional problems of youth. The school has faced tragic situations, including unsafe abortions, numerous unplanned pregnancies, hazing and initiation rituals that spun out of control, drunken brawls in local taverns and knife fights. Lesotho is not exempt from any of the disquiet that impinges on education at schools and colleges elsewhere in the world. 
Table 2 shows only 3 graduates in 2013. This was because an entire class was expelled for conducting a dangerous and unpleasant hazing ritual. In January 2020, the school hired a full time Safety, Health and Environment (SHE) officer with a brief to monitor emotional states like self-harm and substance abuse, and promote options for recreation. A community is built by working its way through problems described above, and included staff, parents, students, the Board, police, and various local leaders.

- HIV/AIDs hollowed out the society and generated substantial levels of orphan status and broken homes. The collection of even modest school fees is trying, although a draconian zero-tolerance policy for non-payment of fees is not in force. The school strives for redress and amelioration by various means; an advantage of a small institution unbound by rigid rules. At present fees stand at M9,000.00 in total for the two year course (students receive lunch Monday to Friday).

- For many years the Lesotho Revenue Authority (LRA) provided a tax clearance certificate perfunctorily. A sudden change in policy required filing of 10 years of Corporate Income Tax. An accounting imbroglio resulted and it took 18 months to resolve before a tax clearance certificate was provided. In the meantime, cash flow was frozen and many services provided went unpaid. The school followed due process and practiced restraint, but the episode was unkind financially.

- Until the opening of a high level bridge over the Senqu River in 2017, access to the school was trying. Until then, Mohale's Hoek was the nearest town by road, and required a gruelling 4 hour drive, one way, over difficult terrain. The road often deteriorated due to a hiatus over maintenance. This ground down vehicles, people and took time. While Mt. Moorosi was only $3 \mathrm{~km}$ from Bethel and on the main highway, Bethel was nonetheless cut off by the Senqu River. Often logistics proceeded by means of an aluminum row boat to cross the Senqu, or via human porters and steep paths on each side of the river. Enrolment accelerated in 2017.

- In 2004, critical personnel were lost due to burnout, resulting in default of a small start-up loan used to get Solarsoft going. Fortunately, assets were not lost and later remobilized. It was a good idea at the wrong time. The price of PV panels was still in the \$3.00-\$5.00/W USD range, and Solarsoft was being double taxed for VAT on both sides of the border between Lesotho and SA for imports. This made commercial viability impossible. A few years later rational procedures evolved for Lesotho and RSA to share VAT, and the price of PV panels is now $\$ 0.17 / \mathrm{W}$ and wireless communications and smartphones are ubiquitous.

\section{Positive Achievements and Recommendations:}

- Students experience a mature and constructive collegiate program that would otherwise elude them due to exclusion from conventional institutions of higher learning.

- The example set by BBCDC encourages young people to consider careers and vocations outside academia, large corporations, big cities and large institutions. There is life out on a limb.

- Media is awash with huge dreary data sets and wicked problems of staggering complexity and scale. We can be aware of them, but remain unfazed and choose to empower ourselves to change the world one step at a time. Start where you are, use what you have, do what you can. Wicked problems are a gumption trap precipitated by a misdirected focus on inappropriate scale and muddled strategic thinking.

- Align life to the nature of our species, which is to be active and unconfined physically, outdoors most of the time, to actuate the full amplitude of our humanity, physically and mentally, to be an encompassing tool user, transforming and maintaining our surroundings in a wholesome configuration (Anderson, 2003). This is happiness.

- $\quad$ Permaculture values the knowledge and skills of indigenous and marginalized communities, because it is localized and has stood the test of time. Students find their way, and, as can be expected, display an astonishing array of talent, commitment and fortitude. The starched formal education system often misses this because it only gauges a narrow range of potential.

- Globalization is not a threat if we cherry pick what it has to offer and bargain from a position of local asset strength. Development assistance and investment work where there is good momentum on the ground and business and markets drive efficiency and over-institutionalization is avoided.

- Decentralization and localism work. The remote location of BBCDC was an advantage as it avoided distractions from national issues and drama. The nexus framework of food, energy and water is vital and can serve as a template for multiplication of efforts.

- The issue of climate change impacts in the context of Lesotho requires critical clarification. Macro and 
Meso scales are different. While Macro scale climate change impacts certainly exacerbate conditions in Lesotho, the situation is not bettered by ignoring active desertification and land degradation, which is an endogenous variable. Discussions of Climate Change tend to be lop-sided and only emphasize the warming part. In Lesotho the high altitude and specific atmospheric conditions manifest extremely bitter cold due to dehumidification. This fragilizes and stresses horticulture, humans and animals.

- Detenuring would serve the institution well. At present four of the staff, including the author, have permanent employment or tenure. This should be replaced with rolling 3 or 5 year contracts subject to performance evaluation.

- $\quad$ Permaculture is a powerful world-wide network (Lawton, TEDxAjman).

\section{Conclusion and Discussion}

What is mankind's future (Berdyaev, 1952; Niebuhr, 1941; Schabert, 1986)? After passing through militarized security at the entrance to the FAO in Rome, the visitor enters a foyer and encounters a horizontal white marble sculpture of the young Syrian boy who drowned and lay dead on the Mediterranean beach. It is a heartbreaking and unforgettable experience and represents a global failure. Sustainable development is a serious mission. The authors of OCF were engaged in an authentic work of theoretical and practical imagination about the global risks of war, environmental collapse, mass migration and climate change. Remote sensing and comprehensive interdisciplinary studies provide humanity with an unparalleled perspective and vantage point. Sustainable development is not a static utopian endpoint which freezes history, but requires acute historical and scientific management of the human condition. It is an anti-fragile position. The SDGs are a common-sense empirical framework to be understood, measured, monitored, adapted and altered according to circumstances. The premise of the SDGs is local agency and self-sufficiency. Ake concludes with an impassioned justification for embracing self-reliance (Ake, 2001). BBCDC reflects a concerted attempt to design systems that are anti-fragile and appropriate (Taleb, 2012). It did so without great endowments of antecedent capital or experience. David S. Landes found that resource preconditions were less important than social capital, particularly education, when considering prospects (Landes, 1999). In preparation for COP26, calls issue for bifurcation into two streams: urgent action and tedious institutional negotiations (Dawson, 2020). Societies must innovate and adapt to changed circumstances. Failure means relegation, whether stark, gradual or traumatic. Landes' work is a grim reminder that events do not always go well (Landes, 1999; Burja, 2020). Design thinking, methodology and management accelerated the pace of development. The hardship, drudgery and boredom of rural village life is real. Otherwise, urbanization would not continue worldwide at the relentless pace that it does (Banerjee \& Duflo, 2014). On the other hand, specialization, commuting, consumerism, bureaucracy and congestion take another toll personally, and on a planetary scale. Charles Taylor ruminates at length on the shifting psychological and physical ground beneath our feet (Taylor, 1989). Lesotho's society is in the midst of a future crunch now made complete by the spread of smartphones, wireless communication and social media. BBCDC provides grounding in this trying situation. Design thinking humanizes the intellectual, scientific, commercial and industrial revolutions (Voegelin, 1987). As traditional patterns and rhythms of life in Lesotho shift inexorably, Permaculture and the SDGs ease the transition and harness local talent, skill, experience and landscape. Students were and are the full partners in the development of the campus. David Ellerman concludes that “...people have a natural ownership of the fruits of their own labor" (Ellerman, 2002, p. 58).

Over the last 200 years, the industrial revolution has successively urbanized global populations. Lesotho is presently no exception, with the last four extremely dry years accelerating the abandonment of rural villages in a wave of internal economic migration. The spread of $4 \mathrm{~m} \times 6 \mathrm{~m}$ tin shacks on the periphery of urban clusters throughout Lesotho is unmistakable. Some 150 BBCDC students rent accommodation in four villages within a kilometer of the campus, which underlines the scale and availability of deserted houses. Land degradation and undifferentiated urbanization present unique development challenges which need to be solved. Without self-organization within both these nodes, conditions will drift or deteriorate leading in a worst case to desperation rather than betterment. For good reason the World Bank (WB) now has a special unit for fragility and conflict. Graduates are provided with skills and attitude to turn both these situations around. Permaculture and design inform both the rebirth of neglected land and the differentiation of emergent urban conditions. Graduates are encouraged to deliver services instead of waiting for services to be delivered. Partnerships for the Goals, SDG17, is prescient in this regard, which means that articulation....emergence resonates, meaning that action on the ground harmonizes and is a rational constellation of numerous large and small institutions, centralized and decentralized, including business. 
The week of June 1-5, 2020, captures the essence of work and activities at the school. Several important milestones were achieved despite Covid-19. Covid-19 restrictions meant curtailed operations and only the $2^{\text {nd }}$ year students have been present since May 13. They graduate at the end of June and everyone is wearing masks and practicing distancing and elevated hygiene. Activities proceed despite the cumbersome circumstances. Two new guest flats were completed for visitors, and the final touches include installation of two low pressure solar water heaters. These flats are not being used, so water is boiling in the afternoon, and bursts of steam and hot water are jetting out of the pressure relief line which is impressive in the cool, clear and dry winter air. A new septic tank was completed for these flats and includes a flow through biogas dome (an inverted 500 litre plastic tank). The overall cost is just slightly more than for a regular septic tank. On Friday, an AC pump was installed in a new borehole drilled in March on the campus. It is powered by solar power from a staff house where a large inverter and solar array is installed. Tests indicate a flow rate of 1800 litres/hour. Students did all the plumbing and laid an underground cable. Welding for support structures and concrete work was also involved. Another crew travelled to Ha Patsa, about $175 \mathrm{~km}$ away, and completed installation of a DC solar pump at the site of a ground water dam built in partnership with FAO. The border to SA is closed but BBCDC managed to find couriers to supply the necessary equipment and arrange for payment. Experiential learning and memories are the result. The school received M265,500.00 for the job in Ha Patsa, and M80,000.00 for another solar pumping project at Malealea. Education and enterprise (meeting the payroll) combines with earning a livelihood. All the investment on the campus is financed internally, with the school presently holding cash reserves to operate without distress for another 12-18 months of Covid-19 lockdown if necessary. On August 11, 2020, the school purchased a $4^{\text {th }}$ container of SWHs through international trade for $\$ 12,820.00$ USD, and in previous weeks purchased over M200,000.00 worth of solar photo-voltaic equipment locally. Work crews and staff are fully booked for the next months.

The question of how societies sustain themselves is an ancient one. The wizened Plato who experienced the collapse of his own city responded by founding a school, and also had these blunt prescriptions: never fortify the city (no walls) and direct the Junior Cadets to camp at night around the perimeter to buffer and repulse any assault (Plato, Laws). The historian John Ralston Saul puts a contemporary face on the moral hazard of social and organizational drift. He provides numerous examples of how a headquarters, general staff, size, bureaucracy, and centralization operate as an existential disconnect and severing of central nervous system (Saul, 1992). In literature Robert Musil filled three volumes (The Man Without Qualities) underlining the sleep walk of a society into oblivion, all the while buoyed by delusions of grandeur (Musil, 1954). In a lighter vein, Joan Magretta describes how non-profits and well-wishers squander inheritances "herding cats" (Magretta, 2002). Taleb is so sure of the inevitability of organizational derailment that he calls for mandatory sunset clauses that terminate organizations with complete liquidation of assets and dismissal of staff (Taleb, 2012). While a bowling club may be easy enough to dismantle, countries and nations less so. Markets and democracy both provide discipline while remaining open systems that invite evolution. It is the task of effective leadership to simplify complexity (Drucker, 1967). Democracy is a variegated term that includes due process, consistent policy, institutional memory, merit, accountability, responsibility, professionalism and transparency. In parallel, markets do not just mean simple trade and price bargaining, but are underpinned by significant assets, infrastructure, finance, regulatory compliance, legal provisions, intellectual capital, expertise, and so on.

The question of endurance naturally arises. There is no auto-pilot. Only good governance and continued exposure to market pressures can prevent the school from going off the rails. No policy or legalese is a substitute for the thrust of articulated purpose and teleology. This paper presents clear empirical results tested by reality for over 25 years, neither perfect nor cynical, but an optimistic experience of human potential which prefers green swans to black ones (Elkington, 2020). It illustrates a realm of alternative pathways, pioneering a new frontier and reflects transition. A broad suite of impact OVIs were presented that includes water, energy infrastructure, shelter, energy systems, cash flow, student numbers, investment, research, outreach, employment, and social capital with significant application to the SDGs.

The existential question of valid purpose drives a wedge into personal, social and historical existence at all times with response varying from dead-ends and outright misery, to vaulting achievements of human imagination and excellence (Voegelin, 1952). It is misleading to think that we can control or predict the future. Foresight and vision, however, are as old as human culture and civilization. Imagination can delude us, or compel and inspire us. There are many competing versions of the Promised Land; it is the task of education to provide clarity and coherence regarding choice and action (Arbib \& Seba, 2020). BBCDC is an ambitious and thoughtful venture in movement towards the SDGs, the year 2030 and further potential. A sound head start is largely due to applying the first principles of Per- 
maculture, Education and Enterprise and a clear mission, strategic framework and purpose fit for context. Multiple tasks remain, including reversing desertification on a broader front, electrification of transportation, job creation through cottage industries, along with steady displacement of food imports to Lesotho. This work represents exodus and a measurable path direction with good options and solid capacity; thinking globally and acting locally.

"You must be the generalist, the activist, the doer" (Lowry, 1988).

Khotso, Pula, Nala (Peace, Rain, Prosperity)

\section{Acknowledgements}

Great thanks to the following organizations and individuals: UNICEF, RC Bishop of Mohales Hoek, Ireland Aid, Solon Foundation, AEE-Intec: Austria, the OPEC Fund for International Development, Emirates Energy Award, Dr. Jene M. Porter, Dr. Thomas A. Lawand, Dr. Elizabeth Westaway, Barbara Kofler, David Muller, Thuso Green, colleagues and students.

\section{References}

African Development Bank. (March 2020). Kingdom of Lesotho: Country Strategy Paper 2020-2024.

Ake, Claude. (2001). Democracy and Development in Africa. Brookings Institute Press. Washington DC.

Alexander, Christopher, et al. (1977). A Pattern Language. Oxford University Press. Oxford.

Alley, Richard B. (n.d.). Earth: The Operators’ Manual. WW Norton and Co. New York.

Anderson, Raymond CEO of Interface Carpets. (2003). The Corporation.Zeitgeist Films.

Arbib, James, Seba, Tony. (n.d.). RethinkX: Disruption, Implications and Choices.

Austen, A. and Duncker, Louiza. (2002). Urine Diversion: Ecological Sanitation Systems in South Africa. Council for Scientific and Industrial Research, RSA.

Banerjee, Abhijit V. and Duflo, Esther. (2011). 14.73x The Challenges of Global Poverty. EDX 2014. Poor Economics. Public Affairs. Philadelphia.

BBCDC. (2007-2019). Annual Review.

Bebbington, Jan. and Unerman, Jeffrey. (2018). "Achieving the United Nations Sustainable Development Goals: An Enabling Role for Accounting Research.” Accounting, Auditing and Accountability Journal, Vol. 31. No. 1, pp. $2-24$.

Beinhocher, Eric D. (2006). The Origin of Wealth. Harvard Business School Press. Boston.

Berdyaev, Nicolas. (1952). The Beginning and the End. Greenwood Press Publishers. Westport.

Burja, Samo. (2020). “Why Civilizations Collapse.” Bismarck Analysis and the Long Now Foundation.

Diamond, Jared. (1998). Guns, Germs and Steel. Vintage. London.

Drucker, Peter F. (1967). The Effective Executive. Elsevier. Amsterdam.

Easterly, William. (2006). The White Man's Burden. Penguin Press. New York, 2006.

Elkington, John. (2020). Green Swans: The Coming Boom in Regenerative Capitalism. Fast Company Press.

Ellerman, David. (2002). "Autonomy respecting assistance: Towards new strategies for capacity building and development assistance.” In SakikoFukudu-Parr et al. (Eds.), Capacity for Development: New Solutions to Old Problems, Earthscan. New York, UNDP.

FAO. (2015). Status of the World's Soil Resources, Main Report 2015.

Fokuoka, Masanobu. (1978). The One Straw Revolution. Rodale Press, Emauss.

Fuller, R. B. (1978). Operating Manual for Spaceship Earth. E. P. Dutton New York.

Hawken, Paul. Lovins, Amory. Lovins, and L. Hunter. (1999). Natural Capitalism. Little, Brown and Co. New York.

Hayek, F. A. (1944). The Road to Serfdom. University of Chicago Press. Chicago.

Hickel, Jason. (n.d.). “Degrowth: a Theory of Radical Abundance.” Real-world Economics Review, issue no. 87.

Hind, P. Magala, S. Millar, and Carla. (2012). "Sustainability and the Need for Change: Organizational Change and Transformational Vision.” Journal of Organizational Change Management. June. 
https://mars.jrc.ec.europa.eu/asap/files/special_focus_2019_12.pdf.

https://twitter.com/PaulEDawson/status/1255693103480156168?s=20.

https://youtu.be/SUNpjlNq2o0.

Jaeger, Werner. (1967). Paideia: The Ideals of Greek Culture Volumes 1-3. Oxford University Press, Oxford.

Kingdom of Lesotho, Bureau of Statistics, Education Statistics Report 2014.

Lall, Sanjaya. (2002). “Social Capital and Industrial Transformation.” In Sakiko Fukudu-Parr et al. (Eds.), Capacity for Development: New Solutions to Old Problems, Earthscan. London, UNDP.

Lancaster, Brad. TEDx Tucson. https://www.youtube.com/watch?v=I2xDZlpInik

Landes, David S. (1999). The Wealth and Poverty of Nations. W.W. Norton, New York.

Lawton, Geoff. (n.d.). TEDx Ajman. https://www.youtube.com/watch?v=-CxP0Thljr4.

Lesotho Solar Thermal Technology Roadmap and Implementation Plan. (2019). BBCDC and NUL.

Lowry, William P. (1988). Atmospheric Ecology for Designers and Planners. Van Nostrand Reinhold.

Magretta, Joan. (2002). What Management Is. Harper Collins. Hammersmith, 2002.

Makarenko, Inna and Plastun, Alex. (2017). "The Role of Accounting in Sustainable Development.” Accounting and Financial Control, 1(2): 4-12.

McCallum, Ian. (2005). Ecological Intelligence. Fulcrum. Golden.

McNeill, J. R. (2000). An Environmental History of the $20^{\text {th }}$ Century World. WW Norton and Co. New York.

Miller Jr, Tyler G. (2000). Living in the Environment. 11th Edition. Brooks/Cole. Pacific Grove.

Mollison, Bill. (1988). Permaculture: A Designer's Manual. Tagari. Tyalgum.

Musil, Robert. (1954). The Man Without Qualities, Vol. I, II, III. Pan Books, London.

Niebuhr, Reinhold. (1941). The Nature and Destiny of Man. Charles Scribners’ Sons. New York.

Oke, T. R. (1987). Boundary Layer Climates. $2^{\text {nd }}$ Ed. Routledge. London.

Orr, David W. (2000). Guest Essay: “The Ecological Design Arts,” in G. Tyler Miller, Living in the Environment, Brooks/Cole. Pacific Grove.

Paoletto, Glen. (1999). “Urban Governance in the New Economy.” In Takashi Inoguchi et al. (Eds), Cities and the Environment. United Nations University Press, Tokyo.

Pimental, D. Westra, L. Noss, Reed, F. (Eds.) (2000). Ecological Integrity. Island Press. Washington, DC.

Plato. (1961). “The Laws.” In Collected Dialogues, Edith Hamilton and Huntington Cairns (Eds.). Princeton University Press. Princeton.

Preston-Whyte, R. A. and Tyson, P. D. (1989). The Atmosphere and Weather of Southern Africa. Oxford University Press, Cape Town.

Raworth, Kate. (2017). Doughnut Economics. Random House. London.

Rimkus, Susan and Lauzon, Al. (2003). "The Learning Revolution.” The Bulletin. Association of Commonwealth Universities, No. 143, April 2003.

SADC: Renewable Energy and Energy Efficiency: Status Report 2018, REN21, SACREEE.

Saul, John Ralston. (1992). Voltaire's Bastards. Penguin Books. Toronto.

Schabert, Tilo. (1986). "Modernity and History II: On the Edge of Modernity?” In Athanasios Moulakis (Ed.), The Promise of History. Walter de Gruyter, Berlin.

Schabert. Tilo. (1986). “Modernity and History I: What is Modernity?” In Athanasios Moulakis (Ed.), The Promise of History. Walter de Gruyter, Berlin.

Schumacher, E. F. (1973). Small is Beautiful: Economics as if People Mattered. Harper.

Smith, J. Russell. (1929). Tree Crops: A Permanent Agriculture. Harcourt, New York, Walden Labs.

South African National Roads Agency. (2007). Design and Construction of Surfacing Seals, TRH3 2007.

Southwick, Charles. (1996). Global Ecology in Human Perspective. Oxford University Press. Oxford.

Taleb Nassim. (2012). Anti-fragile. Incerto Series. Random House, New York. 
Taylor, Charles. (1989). Sources of the Self-The Making of the Modern Identity. Harvard University Press, Cambridge.

Todd, Nancy Jack and Todd, John. (1993). From Eco-Cities to Living Machines. North Atlantic Books. Berkeley.

Voegelin, Eric. (1952). The New Science of Politics. University of Chicago Press, Chicago.

Voegelin, Eric. (1987). In Search of Order, Volume 5. Order and History. Louisiana State University Press, Baton Rouge 1987.

Wahl, Daniel Christian. (2016). Designing Regenerative Cultures. Creative Commons. Axminster.

Water: A Precious Resource in Arid Environments. CBBCDC, 2002.

Whitefield, Patrick. (2004). The Earth Care Manual. Permanent Publications. East Meon.

World Bank Group/UNDP Lesotho. (2020). Assessment of the Socio-Economic Impact of COVID-19 on the Kingdom of Lesotho. P. 8. June, 2020.

World Bank. https://www.worldbank.org/en/country/lesotho/overview.

World Bank. https://www.worldbank.org/en/country/lesotho/overview

World Commission on Environment and Development. (1987). Our Common Future.

Yaholnitsky, Ivan D. (1997a). “A Good Fight in Lesotho.” Sidelines, Southern African Quarterly, No. 11, Winter 1997, pages 34-45.

Yaholnitsky, Ivan D. (1997b). "Using Solar Energy in Lesotho.” Sunworld, International Solar Energy Society, Volume 21, No. 3, Sept. 1997, pp. 16-18.

Yaholnitsky, Ivan D. (2003). "Holding the Rain.” Magazine on Low External Input and Sustainable Agriculture. June, 2003.

Yaholnitsky, Ivan D. (2004). “Progress in Solar Energy Use in Lesotho.” Refocus. May/June 2004

Yaholnitsky, Ivan D. (n.d.). "Case Study: Teaching Sustainable Settlement Design in Lesotho.” In Joseph F. Kennedy (Ed.), Building Without Borders: Sustainable Construction for the Global Village. New Society Publishers.

Yaholnitsky, Ivan D. (n.d.). “Regenerating the Soils of Lesotho,” Permaculture Magazine, \#25, pages 41-43. 